\title{
BRISMES 1994 Annual Conference
}

\author{
4-6 Safar 1415/ 12-14 July 1994 \\ University of Manchester \\ Manchester, United Kingdom
}

The annual conference of the British Society for Middle Eastem Studies (BRISMES) was hosted by the Department of Middle Eastern Studies at the University of Manchester and concentrated on the theme of "Culture: Unity and Diversity." About two hundred participants deliberated over approximately ninety papers of varying standards, in addition to the three plenary sessions. This was achieved by grouping the speakers, many of whom were from overseas, into thirty-four panels covering such diverse themes as law, politics, language, literature, poetry, culture, identity, history, religion, architecture, mysticism, media, economics, and agriculture. A balance was also maintained between the historical and the contemporary in many of these areas. Each session featured up to five panels, each with between two and four speakers. These were held simultaneously in order to give all of the participants in each session the opportunity to choose the one panel that would be of most interest to them. Some of the panels were hosted by special interest groups: The Society for Moroccan Studies; The Association for Cypriot, Greek and Turkish Affairs; The Manchester University Research Group on Central Asia and the Caucasus; and two panels in memory of Avriel Butovsky.

The focus of the conference's attention was the plenary session on each of the three days. A different guest speaker was present for each session. The most striking presentation was that of Seyyed Hossein Nasr (George Washington University, USA). The opening plenary address was by Bozkurt Güvenç (Ankara, Turkey), and the closing plenary session featured Tayeb Salih (London, UK).

After the opening speeches, Bozkurt Güvenç, currently advisor to the President of Turkey and formerly an anthropologist and architect, was called upon to speak on the "Quest for National Identity in Turkey: Cultural Continuity of Historical Diversities." He began by focusing on the dilemma that a quest for identity generates due to its deep-rootedness in the sociocultural and historical consciousness of people at the individual, collective, local, national, static, and transitional levels. In answer to the question "Who are you?," one's identity is as much dependent on the attitude of the perceiver as it is on the perception that the perceived has of himself or herself. It is therefore 
"at once subjective and objective." Identity is also dynamic in that itneeds constant redefinition and reconfirmation, because, as social contexts change, the reference points to which one's identity is anchored also change. Here he asserted that ideology is one of the main causes of that change that leads eventually to an identity crisis. The quest for "national identity" is therefore a "reflection of the problem of convergence and divergence, of diversity in unity and unity in diversity."

As for the Turks, Güvenç pointed to the interplay between the Turkic, Islamic, and Ottoman heritage of identities in addition to the sense of "otherness" that often determines group and national identities, whereby "we often perceive who we are by setting ourselves against others." As an example, he cited Europe's need of the "other" like the Turks, Africans, and Muslims to promote a common EuroChristian identity. Part of this interplay involved an "acculturation" among all three despite the natural geographical barriers that tend to preserve identities. He claimed that it led to the "Anatolization of the Turks rather than the Turkization of Anatolia," whereby the hunter often becomes the hunted.

Turning to the Turks' religious identity, he claimed that 90 percent would traditionally regard themselves as ummati Muhammadan identity based on a religious millat that would admit neither a linguistic nor an ethnic distinction. However, he felt that this label is more nominal than real, as only about $25-30$ percent of the people identify themselves with the Shari'ah movement. He then analyzed the two attempts made during this century to provide Turkey with a "cultural" identity: Atatürk's largely unchallenged cultural revolution, which was based on secular nationalism, and the Welfare Party's cultural counterrevolutionary reform movement, which emerged only after Atatürk's death. He attributed its growing popularity to the vastly different scenario that has prevailed since the early 1900s: dramatic increases in population, life expectancy, literacy, urbanization, higher educational institutions, and religious adherence.

In his conclusion, he noted that present-day Turkey is undergoing many revolutions, not the least of which is technological, and that all of them are being compressed into a short span of time. For example, there is a shift to a decentralized economy, individual enterprise, less formal education, and membership in civil society. He opined that a single overriding cultural identity is not desirable, but that it would be better for Turkey to recognize a cultural mosaic and a specific Kurdish identity. In response to a question, he pointed to the breakdown of modern society as a worldwide, and not a specifically Turkish, phe- 
nomenon and to the need for morality and religiosity to provide social cohesion and a sense of security during turbulent times.

Seyyed Hossein Nasr, a contemporary Muslim intellectual, author, and a former dean at Teheran University, addressed the conference theme in a vivid manner by traversing the "Middle East, wherever that may be" synchronically and diachronically. He highlighted the diversities that dwell within the single unity that makes up Islamic civilization, like the "intricate and diverse patterns that are carefully interwoven into a single Persian carpet." Drawing upon both his Persian and Sufistic backgrounds, he emphasized the sense of unity that springs naturally from divine unity, while the diversities occur out of the variety with which created matter is endowed. Even the nonMuslim communities that dwell within the Muslim mosaic are socially and culturally homogeneous and are regarded as a part of Islamic civilization. He dealt with about five or six areas that demonstrated this incredible unity that encompasses remarkable diversities: religion, culture, language, ethnicity, nationhood, and modernity.

Nasr reflected upon some of the tensions generated by this diversity, especially after colonization. In addition, he decried the efforts of contemporary Muslim academics who take up the analytical inventions and approaches of western scholars long after they had been abandoned by their proponents and said that this is no more than "picking up the crumbs off the table." He finally called upon all of those inside and outside the Islamic arena to come to terms with Islamic civilization, because it is here to stay with its unity and all of its diversities in spite of those who wish to annihilate it.

In the lively discussion that followed, he touched on the core of the Israeli problem: uprooting and transplanting millions of ethnically, religiously, culturally, and linguistically incompatible foreigners into the midst of a homogeneous and settled Middle East. $\mathrm{He}$ also pointed to the new trend amongst modernist Muslims who, up until World War II, looked up to the West as a source of emulation but have since begun to look away because of the West's reporting of its own malfunctioning through its media and literature.

Tayeb Salih, a Sudanese literary figure based in London, was the conference's third and final plenary session speaker. Introduced as "one of the best writers in modern Arabic literature and more deserving of awards than some others," Salih struggled to speak on "The Sense of Identity in Early Arabic Poetry." He began by confessing, in a reference to the conference's theme, to a personal feeling of oddity and diversity amidst the unity, something that has dogged him all his life. Furthermore, as a Sudanese, he said that he was called upon con- 
stantly to "prove his Arabness" and, as a descendant of the Prophet via a Yemeni tribe that migrated to Sudan, he was distinguished from others as a sharif.

Salih chose Abū al 'Alā's poems about Imru al Qays to elaborate upon the sense of identity emanating from early Arabic poetry. In these poems, erotic images are used to reveal a nostalgic longing for a "virgin, pagan, pre-Islamic paradise where one is free to indulge one's senses and yet where noble qualities also prevail." Extolling the sense of bravado, courage, chivalry, honor, and valor of one's tribe was another common identity-fixing device used by early poets. Therefore, it was rare to find one who was antiwar and did not pay homage to the fighting spirit. One such poem was the one in which Imru al Qays, after living a licentious life, was called upon to avenge his father's murder in the time-honored tribal fashion. He was not eager to do this because, as claimed by some, he was not very manly and also because he resented his father, who had neglected him during his childhood. Duty, however, led him to turn to the other tribes for help. As all were scared of the Banū Asad, he went to Rome and ended up seducing Caesar's wife. Caesar sent him off with a poisoned suit of armor, which eventually killed him at the rest-house of a Jew. When asked to return the armor to Rome, the Jew refused, citing his duties as a host, a neighbor, and their (i.e., his late guest's) good qualities. Again, the poem reflects the sense of identity by extolling all of the virtues that Arabs feel are unique to themselves.

Among the papers presented in the Ottoman history panel was one by Azmi Özcan (The Center for Islamic Studies, Istanbul). Entitled "The Issue of an Arab Caliphate in Britain during the Reign of Abdulhamid II," he used it to trace some of the factors that had influenced the relationship between the Ottoman and European powers. He also discussed British duplicity in dealing with the sultan. For example, Britain sought his help in quelling the Indian Mutiny and, after that, enlisted Afghan help against the Russians, while on the other Britain gave active support to the Arab chiefs, called for an Arab caliph, and challenged the sultan's authority in India. This policy was meant to safeguard British trading interests and to check growing pan-Islamic sentiments. Instrumental in whipping up antiOttoman and anti-sultan feelings were the British media, some civil servants, and even some members of the clergy. The sultan, while wary of British intentions, followed the European discussions on Islam and his caliphate with great interest.

In the "Issues in Contemporary Islam" panel, Haifaa Jawad (Westhill College, Birmingham) read her paper on "Female Circumcision: 
Cultural Necessity or Religious Obligation?" She claimed that millions, even today, are forced to undergo this horrific practice in over twenty countries in Africa, Latin America, and the Middle East in Muslim, Christian, and pagan communities, especially (the former) South Yemen, Egypt, and Sudan. Coming from a country in which it is unknown (i.e., Iraq, Iran, Saudi Arabia, Morocco, Jordan), she was shocked, both as a Muslim and as a female, to hear of female circumcision being justified and even advocated by some Muslim "scholars" and "medics."

She set out to research whether it was a case of "Islamizing a cultural practice or a case of culturizing Islam." Having identified and illustrated graphically the three types of circumcision, she traced its origin to ancient Egyptian, African, and Arabian customs. However crude the reasons, Jawad asserted that nothing could justify the pain, the medical complications, the stigma, and the loss of sexuality that this practice engendered. In the absence of any Qur'anic reference, she considered the hadith of Umm 'Āyah too weak to recommend it, let alone enforce it. She concluded that it was a gross violation of women's God-given natural rights and revealed during the question session that it was the women, not the men, who insisted on and perpetrated this practice.

The panel on Islam and secularism was shared by Charles Tripp (SOAS, London) and Abdel Salam Sidahamed (Cambridge University). After giving his definition of "secular" as applied to a modern secular state in his interesting "Islam and the Secular Logic of the State in the Middle East," Tripp contended that Islam, through its beliefs and symbols, has been used in mass politics for selflegitimization and to attain two secular concerns: elite cohesion and social order. As examples, he cited Nasser's socialist Egypt, the FLN's anti-French Algerian identity, Jordan's Hashemite status, and Saudi Arabia's puritanism. This led to the ethno-nationalization of Islam, to growing state control of institutions and persons, and to rising tensions, whereby such secular controlled states or regimes have been challenged increasingly in the same context of mass politics by "Islamic" opposition groups. He hypothesized that both parties were reduced to focusing on four areas of what he termed "the secular logic of modern regimes": welfare issues, a critique of totalitarianism, foreign influences, and violence. He concluded that if "secular logic," in the context of modern mass politics, is used to seize control, then the new regime becomes subject to the same four criteria.

In his paper entitled "From Islamization of Politics to Secularization of Islam: Some Reflections on the Discourse of Contemporary 
Sudanese Islamicists," Sidahamed focused on the interplay between the religious and the secular in the Sudanese political arena. He claimed that secularism was viewed generally in Muslim countries as something foreign, that Sudan was not part of the caliphate until the eighteenth century and was never very Islamic, that much of Islamic law was not enforced even under foreign secular administration, and that Sudan's sectarian plurality was well represented in its secular politics, in which most leaders of the secular sectors belonged to sectarian groups.

In tracing the reordering of political life according to religious criteria, a process that began with the arrival of the Ikhwān in the 1940 s and continued up until their 1991 coup through General Basheer, Sidahamed found that their claims and objectives have become less clearly defined, that their calls for an "Islamic state" have been toned down to calling for the implementation of the Shari'ah and, even further, for the "Islamic hudüd" in the north, and that their calls for such secular ideals as democracy were based on the hope of avoiding Nasser-like repression rather than for Islamic reasons.

Turning to Hassan al Turābī as the man behind the current regime, the speaker noted that his gradual, popularist, and realistic approach helped the movement to reconcile itself with the people and with the government. In spite of al Turābī's progressive and liberal writings and nonorthodox pronouncements, Sidahamed found little evidence of this in practical terms. In his opinion, this indicates a trade-off between ideology and practical state power, because the Islamists' ideology is not clear or practicable and because they lacked experience in government. Thus their movement is being transformed from a religious reform movement to a political one with a religious call.

In the "Press and Journalism" panel, Fahad Tayash, a representative of al Sharq al Awsat (London), referred to some of the challenges facing journalists in his "Pan-Arab Media in Britain: Current Perspective and Future Direction." While claiming that profit was the prime motive, he argued the case for a "moderate" voice by saying that "for too long Arab media has been in the hands of leftists, Ba'thists, and the like." He could not provide satisfactory answers for such questions as to why the flagship newspaper of a country had to be published outside that country or why there was a lack of investigative and factual coverage of local events.

Nicolas Pelham (The Middle East Times, Cairo) mumbled through "Censorship in the Middle East." The presentation was based on his experiences as a foreign journalist in Egypt. He claimed that, despite 
substantial western support, the president's much-acclaimed liberal policies were farcical, as even the local press depends on foreign news agencies. Foreign events get far more coverage quoting foreign state officials instead of local ones, while reports on "friendly" neighboring states are heavily censored. Demonizing the opposition as fundamentalists and terrorists was a popular past-time, and yet investigative journalism was almost nonexistent-except for what is uncovered by foreign journalists and often ends in visits to the publications control office or even to prison. He concluded that "they were as much concerned with censoring naked truth as they were with naked bodies."

Rudolph Peters, a speaker in the "Law and Order in NineteenthCentury Egypt" panel,made some interesting observations in his "Rape, Murder, and Abuse of Power in Nineteenth-Century Egypt: The Case of the Fisherman's Daughter." By selecting such a case, he was able to demonstrate not only how the criminal justice process operated at that time, but also noted the contrasting consequences arising out of the same trial coming before the religious judge (qädî) and then before the legal (qānūn) court.

In another panel on law, Zainuddin Jaffar (Edinburgh University) reflected on religious-secular tensions in his "Development of Islamic Legal Thought in Twentieth-Century Malaysia with Reference to the Influence of the Ottoman Majallat al Ahkäm al "Adliyah." After a gradual imposition of British law, with the exception of Islamic personal law in a few sultanates in which no effort was spared to demonstrate the superiority of British law and thinking over their Islamic counterparts, tensions arose between religious aspirations and secular interests. Paradoxically, the arrival of a Hanafi legal treatise, in the form of the Ottoman Majallat, in a wholly Shäfi'i domain filled the need of the hour by acting as a model for codification in a modern sense. In Johor, it was translated into Malay and accepted in toto, while other states (i.e., Kelantan) requested copies of it. Interest in it grew, which led to its translatioin into modern Malay. It is now studied and taught at universities. The Majallat, he concluded, has also been used to develop banking, commercial, and land laws.

The nonacademic side of the conference featured a book exhibition, among other events, for about twenty publishers specializing on Middle Eastern affairs. Two Muslim publishers-the International Institute of Islamic Thought and the Islamic Foundation-displayed their publications for the first time at a BRISMES event.

After the annual general meeting of BRISMES, which was held during the conference, it was announced that next year's conference 
would be held at the University of Durham. In the words of one of the organizers, this year's event was successful organizationally, both in terms of the numbers attending and also in the quality of papers presented (barring a few).

Abu-Bakr M. Asmal Manchester, UK 